\title{
Wastewater Marine Disposal through Outfalls on the coast of São Paulo State - Brazil: An overview
}

Jayme Pinto Ortiz* | Jacqueline Pedrera Yanes / Antonio Braulio Neto

DOI 10.4322/dae.2016.015

\section{Abstract}

According to the water's fitness for bathing/swimming Report of 2011, São Paulo state coast has a population of over two million people, which can be duplicated in the summer and only reaches a wastewater collection rate of $56 \%$ on average. In the recent years, the investments of São Paulo government and of the Japan Bank have allowed a significant improvement in the collection rates and in the treatment of wastewater in the São Paulo coast. However, it remains necessary to improve the technical alternatives with a more wide vision of problem. The aim of this work is to present an overview of sewage disposal through submarine outfalls in the coast of São Paulo state, as well as, discuss new alternatives to be considered, to help the decision makers in the choose among wastewater treatment systems alternatives, taking into consideration the technical solutions, the cost benefit analysis, the environmental impact and the current environmental legislation, looking maximizing sustainable development in the region.

Keywords: submarine outfalls, domestic wastewater, computational simulation, environment preservation, modeling.

\section{Sumário}

De acordo com o Relatório de balneabilidade de 2011, o litoral de São Paulo tem uma população de mais de dois milhões de pessoas, que pode ser duplicada no verão e só atinge uma taxa de coleta de águas residuais de $56 \%$ em média. Nos últimos anos, os investimentos do governo de São Paulo e do Banco do Japão têm permitido uma melhora significativa nas taxas de coleta e no tratamento de águas residuais na costa de São Paulo. No entanto, continua a ser necessário melhorar as alternativas técnicas, com uma mais ampla visão do problema. $\mathrm{O}$ objetivo desse trabalho é apresentar uma visão geral de disposição de esgoto através de emissários submarinos na costa do estado de São Paulo, bem como, discutir novas alternativas, para ajudar os tomadores de decisão na escolha entre alternativas de sistemas de tratamento de águas residuais, levando em consideração as soluções técnicas, a análise de custo-benefício, o impacto ambiental e da legislação vigente, procurando maximizar o desenvolvimento sustentável na região.

Palavras-chave: emissários submarinos, águas residuais domésticas, simulação computacional, preservação do meio ambiente, modelagem.

Jayme Pinto Ortiz: Dr. Eng. Professor, University of São Paulo Polytechnic School São Paulo, Brasil Antonio Braulio Neto: MSc. Student, University of São Paulo Polytechnic School Jacqueline Pedrera Yanes: Dr. Student, University of São Paulo Polytechnic School 


\section{INTRODUCTION}

According to the Brazilian Association of Sanitary and Environmental Engineering (Associação Brasileira de Engenharia Sanitária e Ambiental - ABES 2005) there is the need for investing of 4.5 billions of dollars yearly over the next 20 years in country-wide sanitary services which, nowadays only attend to the needs of $42 \%$ of the population, in terms of sewage collection (SNIS 2007). In coastal cities where several forms of human activity are involved like tourism, nautical sports, fishing, navigation, aquaculture, and water quality control it must follows the development of these cities to preserve the human activities mentioned above.

In 2007, the Clean Wave Program (Programa Onda Limpa) was launched by São Paulo Government State with the objective to improve the wastewater collection and treatment in the São Paulo coast. São Paulo government and Japan Bank-JBIC investments has been allowing a significant improvement in the collection and treatment rates of waste, although still far from levels of devel- oped countries. The program foresees, in the period that began in 2007 and should be completed by the end of this decade, investments of $R \$ 4.4$ billion. (SABESP, 2014)

These investments must increase the levels of wastewater collection and treatment in São Paulo coast, minimizing the morbidity rates and children hospitalization by water contamination; improving the beach water quality; recovering coastal rivers water quality as well as improve the environmental quality and the social development in these regions. Table 1 shows the collection and treatment wastewater index in the main municipalities of São Paulo coast before and after Clean Wave Program.

However, it is necessary to improve the technical solutions and, although the decision makers should follow the state of art, they should also follow the benefit coast alternatives analysis, looking the cost and the environmental impact of each alternative technically possible, to be adopted in São Paulo and Brazilian coast.

Table 1: Collection and treatment wastewater index evolution with Clean Wave Program (SABESP, 2014).

\begin{tabular}{|c|c|c|c|c|c|}
\hline \multirow{2}{*}{ Region } & \multirow{2}{*}{ Municipality } & \multicolumn{4}{|c|}{ year } \\
\hline & & 2007 & 2010 & 2012 & 2015 \\
\hline \multirow{4}{*}{ 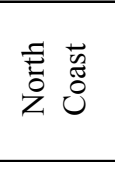 } & Caraguatatuba & $35 \%$ & $70 \%$ & $78 \%$ & $85 \%$ \\
\hline & São Sebastião & $44 \%$ & $46 \%$ & $76 \%$ & $91 \%$ \\
\hline & Ubatuba & $28 \%$ & $36 \%$ & $60 \%$ & $84 \%$ \\
\hline & Ilhabela & $4 \%$ & $36 \%$ & $62 \%$ & $86 \%$ \\
\hline Region & Municipality & $\begin{array}{c}\text { prior to the } \\
\text { program }\end{array}$ & $\begin{array}{l}\text { 1st Stage } \\
(2007-2012)\end{array}$ & $\begin{array}{c}\text { complementary } \\
\text { works } \\
(2013-2016) \\
\end{array}$ & $\begin{array}{l}\text { 2nd Stage } \\
(2015-2020)\end{array}$ \\
\hline \multirow{10}{*}{ 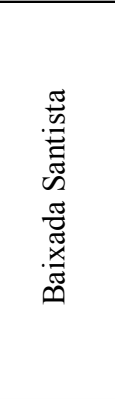 } & Bertioga & $28 \%$ & $35 \%$ & $55 \%$ & $95 \%$ \\
\hline & Guarujá & $57 \%$ & $74 \%$ & $84 \%$ & $95 \%$ \\
\hline & Mongaguá & $21 \%$ & $74 \%$ & $85 \%$ & $95 \%$ \\
\hline & Praia Grande & $46 \%$ & $67 \%$ & $84 \%$ & $95 \%$ \\
\hline & São Vicente & $61 \%$ & $75 \%$ & $83 \%$ & $95 \%$ \\
\hline & Cubatão & $31 \%$ & $51 \%$ & $73 \%$ & $95 \%$ \\
\hline & Itanhaém & $11 \%$ & $31 \%$ & $59 \%$ & $95 \%$ \\
\hline & Peruíbe & $17 \%$ & $71 \%$ & $72 \%$ & $95 \%$ \\
\hline & Santos & $96 \%$ & $97 \%$ & $97 \%$ & $95 \%$ \\
\hline & RMBS & $53 \%$ & $72 \%$ & $82 \%$ & $95 \%$ \\
\hline
\end{tabular}




\section{OBJECTIVE}

The objective of this work is to present an overview of wastewater marine disposal through outfalls in the coast of São Paulo state and to present a discussion of new alternatives to be considered, to help the decision makers in the alternatives choose of wastewater treatment systems, taking into consideration technical solutions, cost benefit analysis, environmental impact and legislation, looking maximizing sustainable development in the region.

\section{COAST OF SÃO PAULO STATE}

In São Paulo State, the most populous and developed, located in southeastern Brazil, the predominant treatment process is treatment through activated sludge. Marine disposal although representing only $2 \%$ of all SABESP (São Paulo Basic Sanitation Company) installations in the state, accounts for $22 \%$ of total waste disposal for treatment, occupying the second place in terms of installed capacity. The reason is that the outfalls in operation in Baixada Santista serve large populations.

To date, the option for sea disposal, with preliminary inland treatment for sanitary discharge (see Figure 1), has competed with inland treatment through activated sludge. Although, improvement are required, the option for marine outfalls offers certain advantages considering the high capacity for sea dispersion, when compared to exclusively inland treatment plants, with the abiding scarcity of both areas and receiving bodies with sufficient capacity for adequate auto-depuration of the effluent, and difficulties in the transportation and disposal of the sludge generated from the treatment process.

Nowadays, for new projects, CETESB is enforcing advanced primary inland treatment.

Monitoring campaigns in specific areas are under way aimed at discerning sea outfall impact on aquatic biota and the quality of bathing water, while also subsidizing both the environmental agency responsible for checking standards of water quality and effluent concentration, and CETESB, in the environmental licensing process. Another very useful instrument in the control and management of generated impacts will be a state law for coastal management of ecological and economic zoning, this constituting the main territorial-wise tool for establishing norms in the occupation and use of coastal resources, besides indicating the most appropriate economic activities per zone.

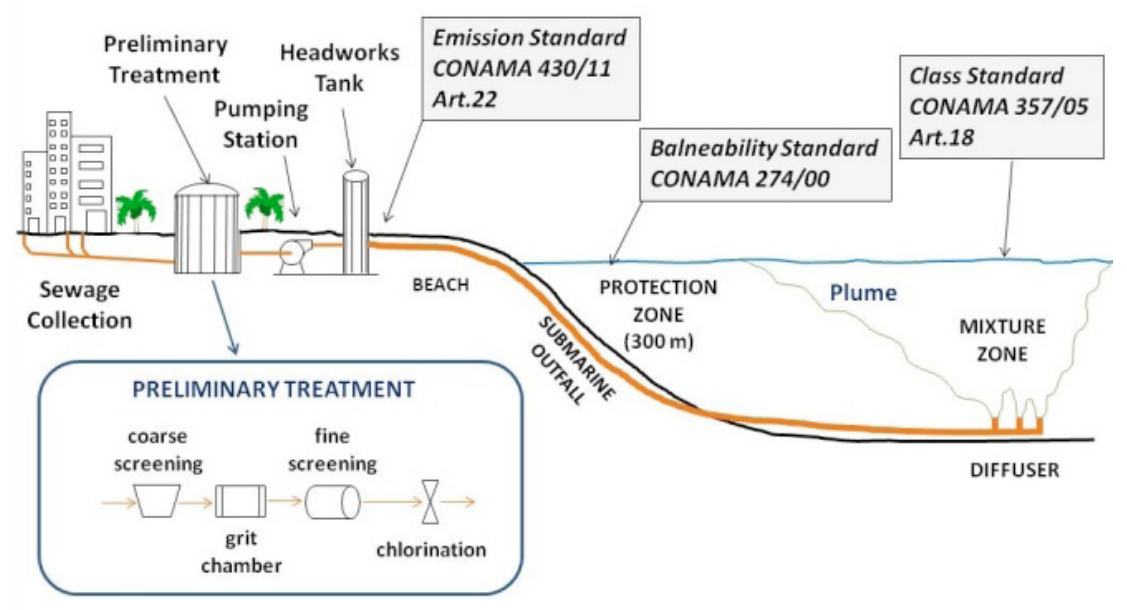

Figure 1: Scheme of a marine outfall coupled with preliminary treatment including grit chamber, screening and chlorination normally used in the SABESP outfalls. 


\section{CURRENT OPERATION AND NEW SEA OUFALLS OF SABESP}

SABESP operates 8 sea outfalls for sanitary disposal with preliminary plants in São Paulo coast (figure 2 and table 2).

The main design characteristics of those in operation are summarized in Table 2.
In table 3 are summarized the maximum flow discharge, the inland treatment characteristics and the begin of operation.

\section{OUTFALLS IN THE "BAIXADA SANTISTA"}

Marine outfalls in "Baixada Santista" have been designed for large populations, as is presented in table 2 .

Table 2: Main characteristics of submarine outfalls on the coastal region of São Paulo (Source: Adapted from http://www.mma.gov.br/port/conama/processos/EFABF603/ Emissarios.pdf)

\begin{tabular}{|c|c|c|c|c|c|c|c|}
\hline $\begin{array}{l}\text { Municipality/ } \\
\text { Location }\end{array}$ & $\begin{array}{c}\text { Maximun } \\
\text { Population } \\
\text { (inhab) } \\
\end{array}$ & $\begin{array}{c}\text { Discharge } \\
\text { Depth } \\
\text { (m) } \\
\end{array}$ & $\begin{array}{c}\text { Outfall/ } \\
\text { Difuser } \\
\text { Length (m) }\end{array}$ & $\begin{array}{c}\text { Outfall } \\
\text { Diameter } \\
\text { (m) }\end{array}$ & $\begin{array}{c}\text { Ports } \\
\text { number }\end{array}$ & $\begin{array}{c}\text { Port } \\
\text { spacing } \\
\text { (m) }\end{array}$ & $\begin{array}{c}\text { Port } \\
\text { diameter } \\
(\mathrm{m}) \\
\end{array}$ \\
\hline $\begin{array}{l}\text { Praia Grande/ } \\
\text { Praia do Forte }\end{array}$ & 253,755 & 12.5 & $\begin{array}{c}3,300 / \\
25(435)\end{array}$ & 1 & $\begin{array}{c}5 \\
(174)\end{array}$ & 16 & $\begin{array}{l}0.175 \\
(0.06)\end{array}$ \\
\hline $\begin{array}{c}\text { Praia Grande/ Vila } \\
\text { Tupi }\end{array}$ & 348,635 & 13 & $\begin{array}{c}3,300 / \\
25(570)\end{array}$ & 1 & $\begin{array}{c}5 \\
(228)\end{array}$ & 14 & 0.175 \\
\hline $\begin{array}{c}\text { Praia Grande/ Vila } \\
\text { Caiçara }\end{array}$ & 559,103 & 13 & $\begin{array}{c}4,095 / \\
420\end{array}$ & 1 & 105 & 5.67 & 0.06 \\
\hline $\begin{array}{c}\text { Santos/ } \\
\text { José Menino }\end{array}$ & $1,322,100$ & 10 & $\begin{array}{c}4,425 / \\
425(200)\end{array}$ & 1.75 & 40 & 5 & $\begin{array}{l}0.011 \\
(0.06)\end{array}$ \\
\hline $\begin{array}{c}\text { Guarujá/ } \\
\text { Praia da Enseada }\end{array}$ & 445,858 & 14 & $\begin{array}{c}4,500 / \\
300\end{array}$ & 0.9 & $\begin{array}{c}150 \\
2 \text { per riser }\end{array}$ & 4 & 0.06 \\
\hline $\begin{array}{c}\text { São Sebastião/ } \\
\text { Praia das Cigarras }\end{array}$ & 1,600 & 8.5 & $1,600 / \quad 3.5$ & 0.16 & 7 & 0.5 & 0.05 \\
\hline $\begin{array}{c}\text { São Sebastião/ } \\
\text { Araçá }\end{array}$ & 21,396 & 17 & $\begin{array}{c}1,215 / \\
24.3\end{array}$ & 0.4 & 6 & 4.2 & 0.09 \\
\hline $\begin{array}{c}\text { Ilhabela/ } \\
\text { Itaquanduba }\end{array}$ & 30,536 & 36 & $\begin{array}{c}941 / \\
32\end{array}$ & 0.45 & $\begin{array}{c}16 \\
2 \text { per riser }\end{array}$ & 4.5 & 0.075 \\
\hline $\begin{array}{l}\text { Ubatuba/ } \\
\text { Enseada }\end{array}$ & 4,437 & 5 & $4,437 /$ & 0.2 & 4 & 2.5 & 0.075 \\
\hline
\end{tabular}

Note: in brackets original design

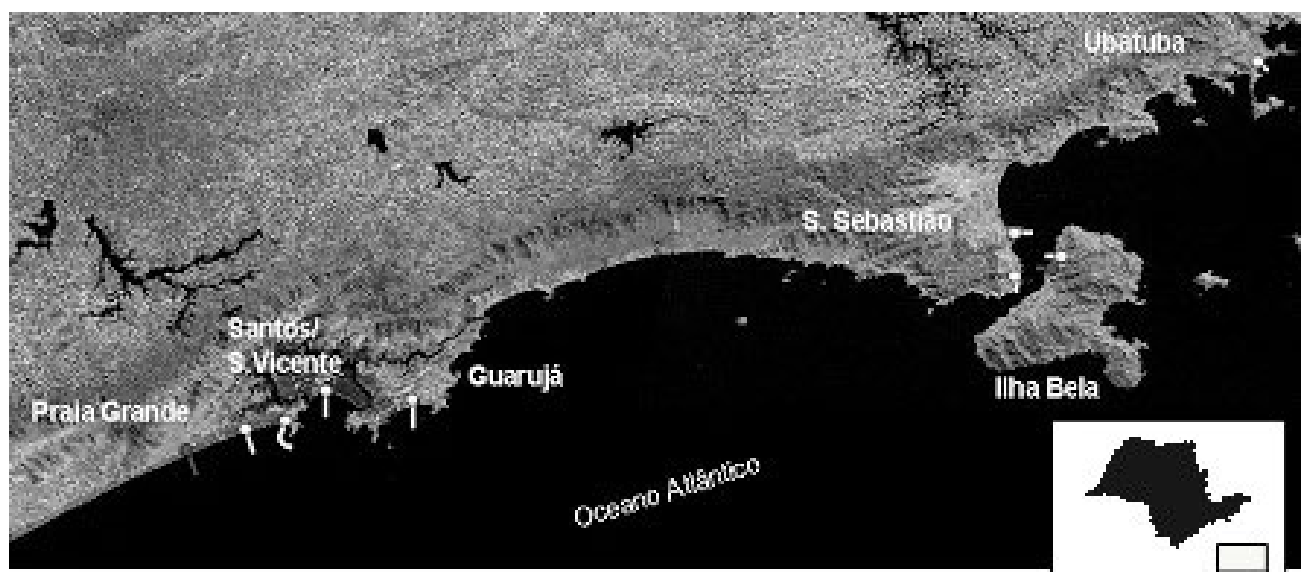

Figure 2: Location of SABESP sea outfalls in operation (Source: Adapted from http://www.mma.gov.br/port/conama/processos/EFABF603/ Emissarios.pdf) 
Table 3: Main characteristics of submarine outfalls inland preliminary treatment (Source: Adapted from http://www.mma.gov.br/port/conama/processos/EFABF603/Emissarios.pdf)

\begin{tabular}{ccccc}
\hline Municipality & Location & Preliminary Treatment & $\begin{array}{c}\text { Maximun } \\
\text { flow (m3/s) }\end{array}$ & $\begin{array}{c}\text { Began } \\
\text { operation }\end{array}$ \\
\hline Praia Grande & Praia do Forte & CS, CH (in the future + GC, FS) & 1.041 & 1996 \\
Praia Grande & V. Tupi & CS, CH (in the future + GC, FS) & 1.047 & 1996 \\
Praia Grande & V. Caiçara & CS, GC, FS, CH & 1.400 & 2010 \\
Santos & José Menino & CS, GC, FS, CH & $5.3(7.267)$ & 1979 \\
Guarujá & Praia Enseada & CS, GC, FS, CH & 1.447 & 1998 \\
São Sebastião & Praia Cigarras & CS, CH (in the future + GC, FS) & 0.012 & 1985 \\
São Sebastião & Araçá & CS, FS, CH & 0.140 & 1991 \\
Ilhabela & Itaquanduba & CS, GC, FS, CH & 0.154 & 2010 \\
Ubatuba & Enseada & $\mathrm{CS}, \mathrm{CH}$ & 0.015 & - \\
\hline
\end{tabular}

Note: in brackets original design CS - Coarse Screening, CH - Chlorination, GC - Grit Chamber, FS - Fine Screening (static and rotating screens (1,0 or 1,5 mm))

\section{Santos Outfall. The System's Historical Conception}

Santos is the oldest marine outfall system in operation along the São Paulo coast serving both Santos itself and the neighboring São Vicente, with a combined population showed in Table 2. Original planning of the system dates from 1969. From additional studies of the SBS - Baixada Santista Sanitation Company, as coordinated by Professor Garcia Occhipinti (Hidroconsult, 1975 apud CETESB, 2006) more precise design and construction criteria for this system were defined, this including the preliminary treatment at José Menino Beach, and a submarine outfall of steal, covered by concrete, starting on the beach with a length of $4 \mathrm{~km}$.

On considering the lack of an adequate waste collection network system in the region, with wastewater flowing into the numerous channels of both towns, these were connected to the oceanic interceptor thereby making it possible, within a certain flood limit, to direct the channel flows to the preliminary treatment plant.

\section{Use of Models to Support Decision Making}

Although the Santos outfall substantially contributed to improving beaches, sea-bathing availability and touristic aspects of the region, its location in the center of the bay caused a certain impact on the mixing zone within the bay itself.

The justification for central placement was based on oceanographic information of a semi- permanent surface current at a depth between 0 to $2 \mathrm{~m}$ formed by the convergence of fresh water coming from Santos and São Vicente estuaries (Marcelino $\&$ Macedo, 2006). More recent studies, using data from physical and numerical models have shown that current behavior is not guarantee of plumeflow seawards. Nevertheless it is worthy of note that the Henry Borden Hydroelectric Power Plant, in operation until 1992, was contributing with a volumetric discharge of between 74 to $131 \mathrm{~m}^{3} / \mathrm{s}$, whereas, nowadays the maximum contribution is only $6 \mathrm{~m}^{3} / \mathrm{s}$, thus certainly contributing to the variation in behavior of currents in the Santos bay.

A distorted hydraulic model was adapted in the $\mathrm{Hy}$ draulic Laboratory of the Polytechnic School using Froude similitude and occupying an area of $750 \mathrm{~m}^{2}$, with a horizontal scale of 1:1,200 and a vertical scale of 1:200. In this model, the sea outfalls of Santos, Guarujá and Praia Grande (subsystems 1 and 2) were reproduced, as well as the Santos estuary and the harbor channel, according with figure 3 (Ortiz et al, 2007 and FEHIDRO, 2008). 


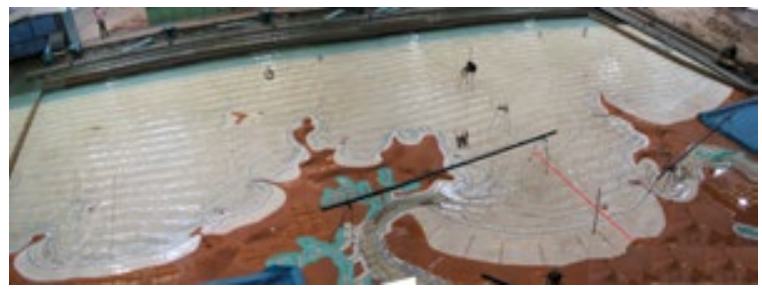

Figure 3: General view of Hydraulic Laboratory physical model (Ortiz et al., 2007)

The results of the physical model show, for some scenarios, the tendency of recirculation inside the bay and at the exit of Santos harbor channel. For a sea outfall extension of $1 \mathrm{~km}$ (outfall length of $5 \mathrm{~km}$ ) the results show a tendency for plume to flow towards the open sea, as is showed in figure 4 after nearly 6 tide cycles reproduced in the model (Ortiz et al, 2007 and FEHIDRO, 2008).

Computer simulations were applied considering $4 \mathrm{~km}$ outfall and the diffuser design presented in Table 2, for design discharge $\mathrm{Q}=5,3 \mathrm{~m}^{3} / \mathrm{s}$, without considering stratification layer.

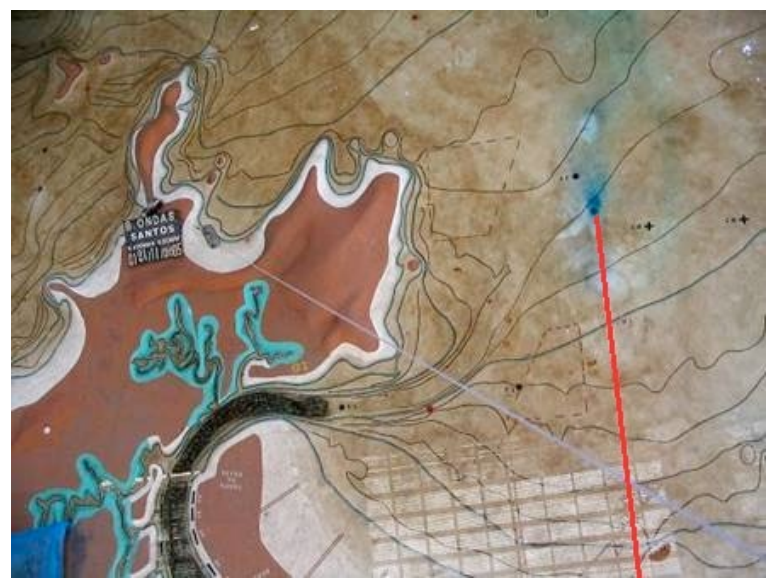

Figure 4: Plume effluent discharge after 6 tide cycle for Santos outfall with 5 km (Ortiz et al., 2007)

In this case, CORMIX 2 for multiport diffusers was employed (Doneker \& Jirka, 2000; Jirka \& Akar, 1991) with phosphorus concentration reaching $0,0837 \mathrm{mg} / \mathrm{L}$ at the end of the near field $(112 \mathrm{~m}$ far from the multiport diffuser point discharge), which resulted in a dilution of $\mathrm{S}=62$ in the region. Additional information on the resultant jet/plume can be seen in FEHIDRO, 2008. The CFD computer code, Fluent 6.1.22 (academic license FLUENT INC., 2003), based on the finite volume technique, was used for transition and far-field computer simulation. The values obtained using CORMIX were inserted into the CFD code as boundary conditions. In this case, a mixture model was used to simulate the multiphase mixture and to solve plume dispersion (see Fluent INC., 2003). Figure 5 presents the data of the transient discharge considering data on tidal variation in the two entrances of the bay, viz. the access channel to Santos Harbor and that of the Mar Pequeno.

These data were inserted in the FLUENT simulations for scenario of $2 \mathrm{~m} / \mathrm{s}$ wind action at $50^{\circ}$ towards the estuary of the bay. The results simulations are reproduced in figure 6 showing that plume circulate and disperse throughout almost all Santos' bay, with dilution values reaching 67, when considering conservative parameter.

This figure shows phosphorus concentration values in the bay for the following tidal instant times (hours): $1 / 4 ; 1 / 2 ; 1 ; 3 ; 6 ; 12$.

\section{New Diffuser and Preliminary Treatment System}

A new diffuser was designed as a step in reformulating the old diffuser of Santos outfall. According with (Subtil et al., 2011), this new diffuser was installed onto the end of the old diffuser, with 425 $\mathrm{m}$ of length, 79 vertical flexible rubber risers with two nozzles of $11 \mathrm{~cm}$ in the exit of each riser, increasing the outfall length in $425 \mathrm{~m}$.

Although the new diffuser will represent an improvement on the dispersion process as a whole in the near-field, dilutions values, for some flow conditions, do not exceed 100. 


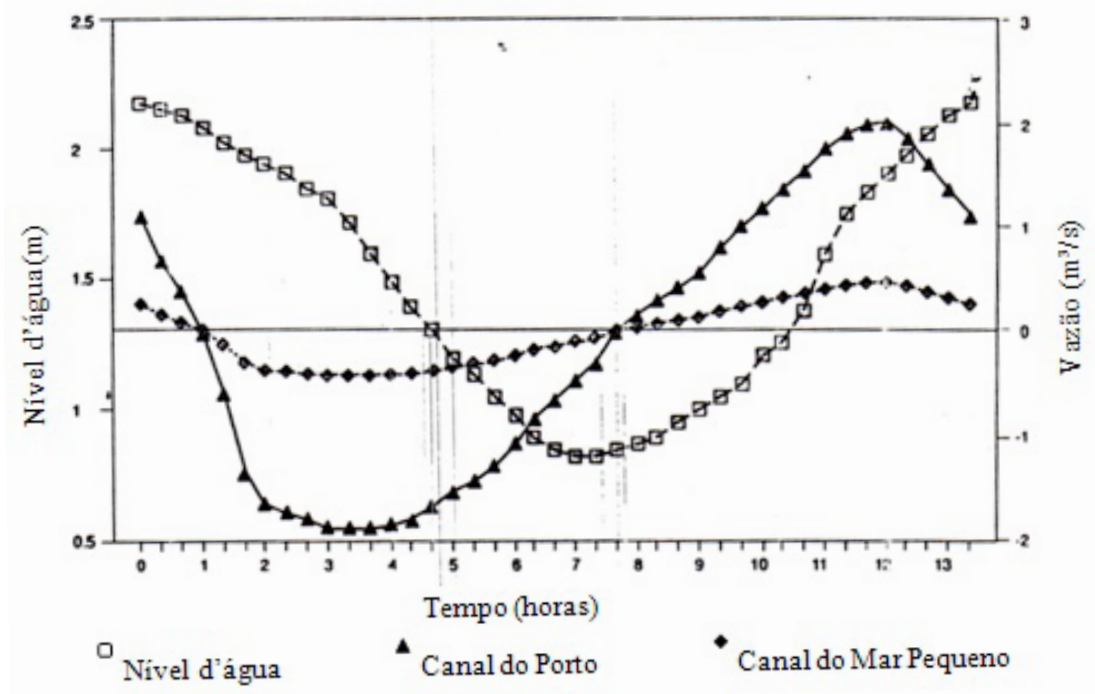

Figure 5: Transient flow and water level in channel harbor and Mar Pequeno exit (Ortiz et al., 2008)

Computer simulations using MIKE 21 were done for the new diffuser design assuming the new design maximum discharge of $5.3 \mathrm{~m}^{3} / \mathrm{s}$ for outfalls of $4 \mathrm{~km}$ and $5 \mathrm{~km}$, respectively. However, instead of use the transient discharge data in Santos Harbor and Mar Pequeno channels, as mentioned above, it was prescribed freshwater flow from the estuary main rivers, assuming mean volumetric flow based in the data measure in July 2005 (SABESP, 2006). Table 4 presents the rivers contributions simulated for the Santos estuary.
Table 4: Mean Flow Rivers discharge in Santos estuary

\begin{tabular}{lc}
\hline \multicolumn{1}{c}{ Rivers } & Mean flow discharge (m3/s) \\
\hline (a) Santana & 1.5 \\
(b) Cubatão & 20 \\
(c) Mogi & 10 \\
(d) Onça & 10 \\
(e) Itapanhau & 30 \\
Total & 71.5 \\
\hline
\end{tabular}

At the open boundary (north) it was prescribed two conditions for simulation of freshwater

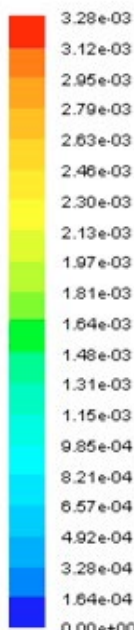

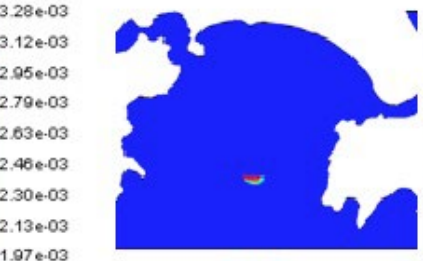

(A)

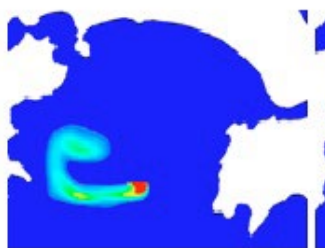

(D)

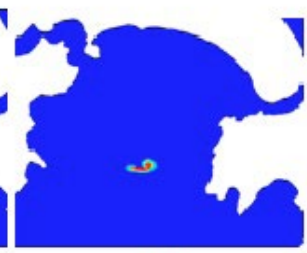

(B)

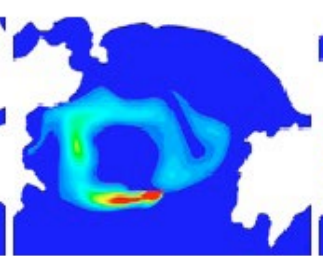

(E)

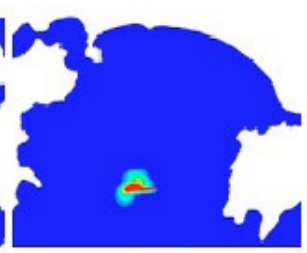

(C)

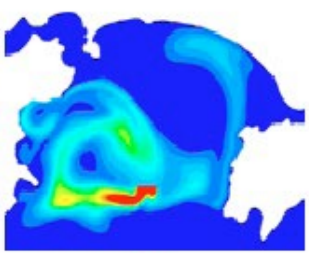

(F)

Figure 6: Plume concentration contours of phosphorous $(\mathrm{mg} / \mathrm{L})$ for the following tidal instant time, with the wind action: (A) 1/4; (B) 1/2; (C) 1; (D) 3; (E) 6 e (F) 12 (Ortiz et al., 2008) 
flow from the main rivers: a critical condition of drought, with almost zero contribution $\left(0.5 \mathrm{~m}^{3} / \mathrm{s}\right)$ and a second condition of $71.5 \mathrm{~m}^{3} / \mathrm{s}$. At the open sea boundary (west) it was prescribed tidal variation. At the open sea boundary (south) it was not prescribed any flow. At the open sea (east) it was prescribed a mean elevation constant value. Wind velocity was assumed constant and equal $2 \mathrm{~m} / \mathrm{s}$ blowing in the north direction toward to the coast. The simulations were done for 4 and $5 \mathrm{~km}$ of outfall extension, respectively, and it was assumed a single point effluent discharge at the exit of the outfall (end of the near field). More details could be seen in Ortiz et al. 2011.

Figure 7 shows the general view of the geometry simulated using MIKE 21.

The hydrodynamic results are presented in Figure 8. Figures $8 \mathrm{~A}$ and $8 \mathrm{~B}$ present the simulations with 4 and $5 \mathrm{~km}$ outfall length, for condition of almost zero flow from the main rivers. Figures $8 \mathrm{C}$ and $8 \mathrm{D}$ present the simulation with 4 and $5 \mathrm{~km}$ outfall length respectively, for condition of $71.5 \mathrm{~m}^{3} / \mathrm{s}$ from major rivers.
The results of the physical model presented in figure 4 shows that $1 \mathrm{~km}$ of outfall length extension diminished the bay recirculation, for the critical condition of low flow from the rivers estuary and wind blowing towards the sea, because there is a tendency of plume to leave the bay toward the open sea (figures $8 \mathrm{~A}$ and $8 \mathrm{~B}$ ).

These results confirm previous results obtained in the distorted physical model (Ortiz et al., 2007 and FEHIDRO, 2008) and in the numerical model using FLUENT.

The increase in the rivers flow to $71.5 \mathrm{~m}^{3} / \mathrm{s}$ contributes to minimize the recirculation inside the bay and to drive the plume outside the bay, for condition of smaller length $(4 \mathrm{~km})$ outfall.

\section{Praia Grande Outfalls (Subsystems 1, 2, 3)}

Marine outfalls of Praia Grande are more suitable when compared with Santos because they discharge in open sea. Three submarine outfalls are in operation in Praia Grande. Subsystem 1 - Praia do Forte and Subsystem 2 - V. Tupi are in operation since 1996, with lengths of 3,300 m. In the design of the subsystem 1, although the standard pre-

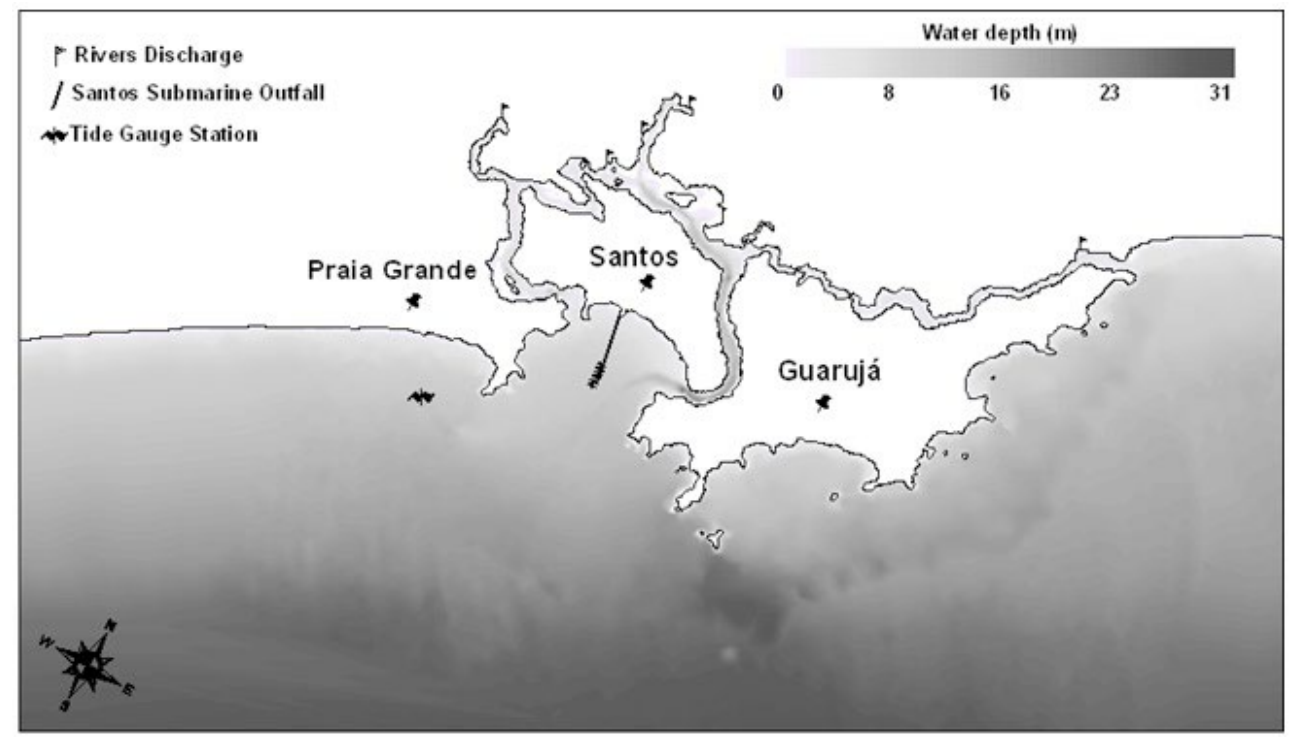

Figure 7: Study area with the bathymetry used in the models (Ortiz et al., 2011). 

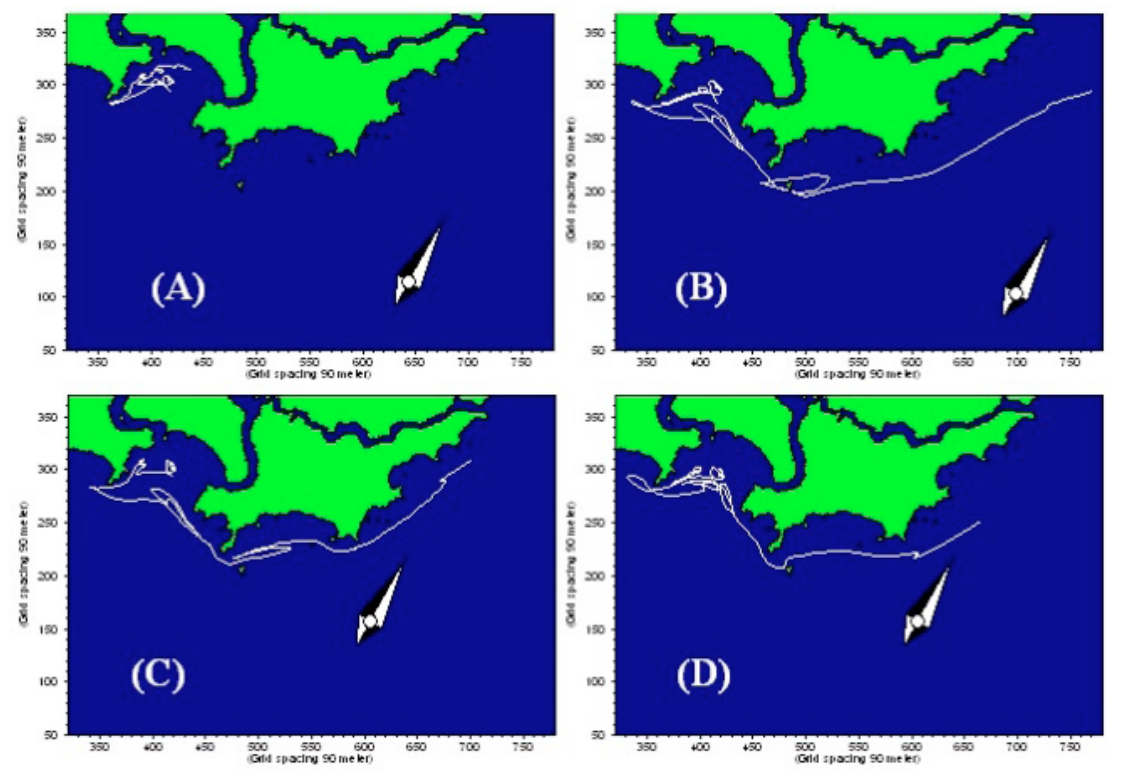

Figure 8: Particle tracking from the outfall effluent discharge exit using MIKE 21. (A) outfall with $4 \mathrm{~km}$ and rivers contribution of $0.5 \mathrm{~m}^{3} / \mathrm{s}$; (B) outfall with $5 \mathrm{~km}$ and rivers contribution of $0.5 \mathrm{~m}^{3} / \mathrm{s}$; (C) outfall with $4 \mathrm{~km}$ and rivers contribution of 61.5 $\mathrm{m}^{3} / \mathrm{s}$; (D) outfall with $5 \mathrm{~km}$ and rivers contribution of $61.5 \mathrm{~m}^{3} / \mathrm{s}$. (Ortiz et al., 2011)

liminary plant was forecast this was not built, thus land treatment was basically composed of screening and disinfection by hypocloride. Furthermore, the design multiport diffuser of 435 meters-long with 174 exit ports, was not installed, this being substituted by a much shorter ( 25 meters-long) diffuser, with 5 exit ports. The same occurred in the subsystem 2 - V. Tupi (see table 2). Subsystem 3 - V. Caiçara is more modern and longer $(4,095 \mathrm{~m})$ and began the operation in 2010 with 420 length diffuser and 105 orifices.

The results of initial dilution of Praia Grande Subsystems are much more successful than the Santos/São Vicente, as the outfalls with 3,300 m can conduct the wastewater towards the open sea, which does not occur in Santos, where the wastewater circulate inside the bay. However it is necessary to improve Subsystems 1 and 2 land treatment, as well as the operating diffusers systems, to better explore the suitable conditions arising from the dispersion process. Computer simula- tions using CORMIX 2 for the subsystem 3 outfall, designed by ENCIBRA S.A. (ENCIBRA 2002), with length of $4 \mathrm{~km}$, considering the diffuser alternative of $420 \mathrm{~m}$ or $298 \mathrm{~m}$ long, with 75 risers, 3 or 2 nozzles each, show, for the worst scenario, initial dilution of order of $S=460$ (FCTH, 2005), which is much higher than the minimum required of 100 .

\section{Guarujá Outfall}

Guarujá outfall with 4500 length, which is in operation since 1998, has a 300 diffuser length and 150 risers, two ports each, according table 2 . The Guarujá outfall has been in satisfactory operation since reconstruction in 1998. Subsequently SABESP began connecting channels to the interceptor, solution that was already used in the Santos outfall, which, associated with the complete collection of the shoreline sewage, resulted in a great improvement of coastal water quality in Guarujá.

In accordance to bathing zone monitoring data compounded weekly by CETESB during 2009, the 
low bacterial concentration is in compliance with the legal limits.

\section{NORTH COAST MARINE OUTFALLS}

Some of the most beautiful beaches of the country are to be found along the north coast, linking the states of São Paulo and Rio de Janeiro. Nevertheless, easy access has improved tourism, although the construction of the necessary infrastructure, especially the waste collection and treatment plants for the communities has been neglected. Clean Wave Program investments is improving this situation, according presented in Table 1, however it is important to discuss the better solution of waste collection and treatment to be applied in the region.

There are four sanitary submarine outfalls in operation in the region: two at São Sebastião city (Araçã and Cigarras), one at Ilhabela (Itaquanduba) and one at Ubatuba (Enseada), which characteristics are presented in Table 2. One other, Saco da Capela at Ilhabela is not in operation. However, the population served in North coast is much smaller (smaller than 50,000 inhabitants), when compared with that of the south coast (greater than 250,000 inhabitants).

The São Paulo's experience in the ocean disposal systems through submarine outfalls is mainly concentrated in large cities. It will be presented in the sequence that this alternative is also a competitive solution for the smaller communities in the northern coast of São Paulo, where are concentrated municipalities with populations of order 50,000 inhabitants or less.

\section{Itaquanduba Outfall}

The old marine outfall of Ilhabela, Saco da Capela, although discharging at a depth of $24 \mathrm{~m}$, is very short, i.e. only 220 meters-long, thereby implying that waste disposal occurs within $300 \mathrm{~m}$ from the coast, in a zone considered as 'bathing protection'. In order to improve this situation, the new Itaquan- duba Marine Disposal System was constructed and is in operation with $800 \mathrm{~m}$ length, $32 \mathrm{~m}$ of extension diffuser and launching the wastewater at $36 \mathrm{~m}$ deep. The population served is 30,536 inhabitants.

According to SABESP, as part of the licensing process for the construction of Itaquanduba outfall, in February 2006 it was carried out a characterization of the São Sebastião channel, in the future area of influence of the outfall, considering normal parameters of seawater quality. Years later, in December 2009, during the emissary's settlement phase, it was carried out another environmental monitoring in the same area, not finding evidence of changes in the parameters analyzed as a result of emissary's construction.

Finally, between July 2012 and July 2013 it was done the first environmental monitoring of this area with the emissary in operation. The results showed that the fecal coliform values and esterococci remain below the legal limit of 1000 MPN/100mL and 100MPN/ $100 \mathrm{~mL}$, respectively, across the area of influence of the outfall in the mixing zone (SABESP, 2013).

The results were compared with those obtained during the two previous monitoring campaigns, showing that the discharge of wastewater through the outfall of Itaquanduba is not changing, in a negative way, the receiving environment (SABESP, 2013).

The efficiency of the Itaquanduba outfall was checked through the simulation of the initial dilution of the effluent plume with the aid of Visual Plume software.

The simulations showed initial dilution values well above 100, even in the diffuser outlet. Although Itaquanduba was designed for a maximum flow of $0.154 \mathrm{~m}^{3} / \mathrm{s}$, currently, operates with a minor flow of $0.05 \mathrm{~m}^{3} / \mathrm{s}$, so the simulations were performed for both cases.

The sanitary effluent receives a preliminary treatment prior to the discharge that comprises sieves 
of $1.0 \mathrm{~mm}$ to sand removal and disinfection by sodium hypochlorite. In both cases, the emissary quickly reaches the legal limits for fecal coliform (1000 MPN/100mL) and enterococci (100 MP$\mathrm{N} / 100 \mathrm{~mL}$ ) established in the current legislation. The results of simulations can be seen in Table 5 .

The results of simulations are consistent with the results of monitoring carried out between 2012 and 2013 and which were discussed above.

\section{Guaratuba - Boracéia Case Study}

The area under study includes five neighborhoods located in the municipalities of Bertioga and São Sebastião: Jardim São Lourenço; Costa do Sol, Morada da Praia, Balneário Mogiano, and Boracéia, as shown in Figure 9. In this figure it is possible to see the Itaguaré, the Guaratuba and the Una rivers.

According to SEADE, the Data Analysis System of São Paulo State (http://www.seade.gov.br), the fixed population of region (winter) is of 9,000 inhabitants. However, in the summer the population could double and could reach the 19,000 inhabitants. Also, in accordance to the study, the population would grow near to $35 \%$ over the next 15 years reaching 25,000 inhabitants in the 2030 .
With the aim of obtaining arguments for selecting the most adequate domestic effluent treatment and management system for this area, na academic reasearch has been developed by EPUSP group. In this research it was compared the alternative of a submarine outfall (ES) designed coupled to a preliminary treatment with a conventional activated sludge primary treatment plant (ETE-LAB) in terms of costs.

Based on Gonçalves \& Souza (1997), Gouvéia et al. (2002) and Garcia (2013) references, two different submarine outfall systems were designed. The first one with 1,500 meters and the second with 2,000 meters of length. Both of systems were evaluated for two different effluent flows, $47 \mathrm{l} / \mathrm{s}$ considering the current population (2016) and 64 $\mathrm{l} / \mathrm{s}$ considering the expected population in 2030. In the Table 6 are showed the main characteristics of the two systems.

\section{Cost Comparison.}

\section{Capital Expenditure (CAPEX)}

Ortiz et al. (2006), Arasaki \& Ortiz (2006), Souza et al. (2007) and Freitas et al. (2011) show that the option to submarine outfalls, in many cases, is a more economic and competitive solution for Brazil and São Paulo coast. The case study corre-

Table 5: Simulations results. Initial dilution and final fecal coliform concentration.

\begin{tabular}{|c|c|c|c|c|c|c|}
\hline \multirow{2}{*}{\multicolumn{2}{|c|}{$\begin{array}{l}\text { Nutrient Initial } \\
\text { Concentration }\end{array}$}} & \multirow{2}{*}{$\begin{array}{l}\text { Effluent } \\
\text { Flow } \\
(\mathrm{m} 3 / \mathrm{s})\end{array}$} & \multirow[t]{2}{*}{$\begin{array}{c}\text { Initial } \\
\text { Dilution }\end{array}$} & \multicolumn{2}{|c|}{$\begin{array}{c}\text { Distance from outlet to } \\
\text { place plume reaches } \\
\text { the surface }\end{array}$} & \multirow{2}{*}{$\begin{array}{c}\text { Coliform } \\
\text { Surface } \\
\text { Concentration }\end{array}$} \\
\hline & & & & $\mathbf{x}(\mathbf{m})$ & y (m) & \\
\hline \multirow{2}{*}{$\begin{array}{c}\text { Fecal } \\
\text { Coliform }\end{array}$} & \multirow{2}{*}{$\begin{array}{c}1,700,000 \\
\mathrm{MPN} / 100 \mathrm{ml}\end{array}$} & 0.050 & 561 & 23.8 & 3.11 & $\begin{array}{c}3,030.3 \\
\mathrm{MPN} / 100 \mathrm{ml}\end{array}$ \\
\hline & & 0.154 & 276 & 24.39 & 3.18 & $\begin{array}{c}6,159.4 \\
\text { MPN/100ml }\end{array}$ \\
\hline
\end{tabular}




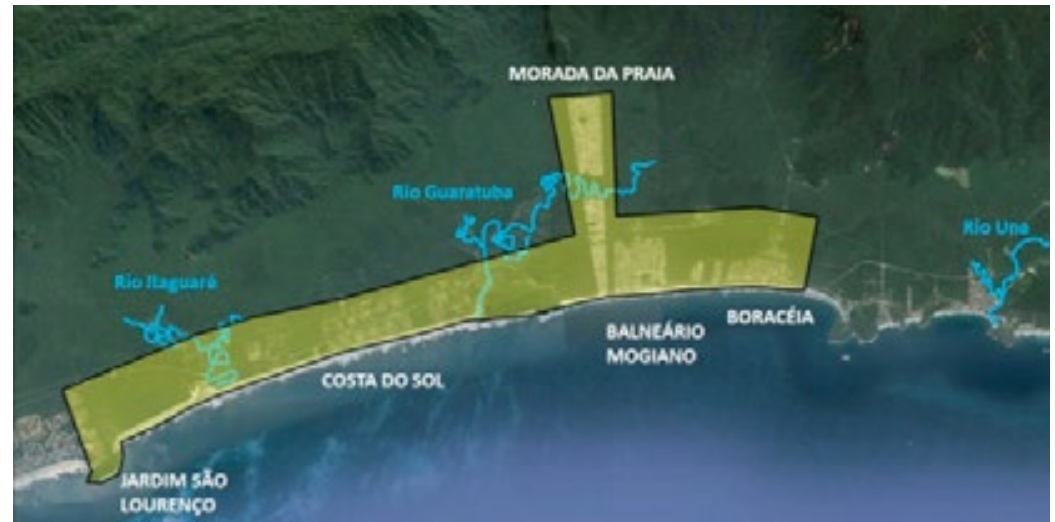

Figure 9: Study area

sponds to a wastewater maximum flow of $64 \mathrm{~L} / \mathrm{s}$ for a summer population estimated of 25,000 inhabitants in 2030.

In order to obtain, for the case study, the estimative cost of construction and installation of the submarine outfall designed, it was calculated cost of the prime material of the outfall (pipe PEAD), outfall installation at sea (boats, dredging and diving team), land preliminary treatment station, pump system, among others, based on updated data from SABESP database. For CAPEX cost of preliminary treatment (PREL) was adopted $20 \%$ of ETE-LAB cost.

The final budget calculated was US\$ 4.4 million for preliminary treatment and design $1(\mathrm{PREL}+\mathrm{ES}(1))$, US\$ 5.5 million for preliminary treatment and design 2 (PREL+ES(2)) and US\$ 4.4 million for ETE-LAB. The installation costs for alternatives $P R E L+E S(1)$ and ETE-LAB are equivalent, unlike the option PREL+ES(2) which it has an increase of $25 \%$ in this cost. This increment is consequence of the $500 \mathrm{~m}$ of PEAD pipeline added.

\section{Operating Cost (OPEX)}

Another important parameter to consider in the cost analysis is the Operating Cost. This analysis was performed considering a current winter population of 19,000 inhabitants and an annual mean flow effluent treatment of $49 \mathrm{l} / \mathrm{s}$ for all alternative systems. The main data for the evaluation of OPEX for ETE-LAB, such as consumption of chemicals, consumption of electricity, sludge disposal, workmanship etc, were also obtained from the

Table 6: Submarine outfalls. Main characteristics.

\begin{tabular}{cccccccc}
\hline Design & $\begin{array}{c}\text { Outfall } \\
\text { length (m) }\end{array}$ & $\begin{array}{c}\text { Outfall } \\
\text { diameter } \\
(\mathbf{m})\end{array}$ & $\begin{array}{c}\text { Discharge } \\
\text { depth }(\mathbf{m})\end{array}$ & $\begin{array}{c}\text { Difusser } \\
\text { length }(\mathbf{m})\end{array}$ & $\begin{array}{c}\text { Ports } \\
\text { number }\end{array}$ & $\begin{array}{c}\text { Port } \\
\text { spacing } \\
(\mathbf{m})\end{array}$ & $\begin{array}{c}\text { Port } \\
\text { diameter } \\
(\mathbf{m})\end{array}$ \\
\hline 1 & 1,500 & 0.315 & 6.7 & 14 & 11 & 1.3 & 0.075 \\
2 & 2,000 & 0.315 & 10.8 & 22 & 11 & 2.2 & 0.075 \\
\hline
\end{tabular}


database of SABESP. These values are presented in Table 7, resulting in a total value of nearly US\$ $26,200 /$ month. In the case of the submarine outfall system were analyzed the same main costs that for ETE-LAB and, in addition, it was considered a cost for effluent plume monitoring. The consumption of chemicals was considered null and the sludge disposal for submarine outfall was considered only $10 \%$ of the cost in ETE-LAB. These values are presented in Table 7, resulting in a total value of nearly US $\$ 14,500 /$ month. The analysis of Table 7 shows that the month OPEX is $80 \%$ greater when the ETE-LAB is adopted. One of the main advantages of alternative of submarine outfall is the reduction in the cost for sludge disposal, when compared with ETE-LAB.

Table 7: Opex Cost summary.

\begin{tabular}{|c|c|c|}
\hline System & ETE-LAB & ES \\
\hline $\begin{array}{l}\text { Water Flow } \\
\text { (m3/month) }\end{array}$ & 128,900 & 128,900 \\
\hline $\begin{array}{c}\text { Chemicals Consumption Cost } \\
\text { (US\$ } \$ \mathbf{m} 3)\end{array}$ & 0.04 & - \\
\hline $\begin{array}{c}\text { Electricity Consumed Cost } \\
\text { (US\$/m3) }\end{array}$ & 0.04 & 0.01 \\
\hline Sludge Disposal Cost (US\$/m3) & 0.05 & 0.01 \\
\hline $\begin{array}{l}\text { Workmanship Cost } \\
\text { (US\$/m3) }\end{array}$ & 0.07 & 0.05 \\
\hline $\begin{array}{c}\text { Monitoring Plume Cost } \\
\text { (US\$/m3) }\end{array}$ & - & 0.05 \\
\hline $\begin{array}{l}\text { OPEX Cost } \\
\text { (US\$/month) }\end{array}$ & 26,200 & 14,500 \\
\hline
\end{tabular}

\section{Total Cost}

Table 8 shows the results of economic feasibility of the alternatives, the total cost is the present value of CAPEX and OPEX costs over 15 years at a $0.5 \%$ monthly rate. In general, for the studied submarine outfall pipeline length range (submerged part between $1,500 \mathrm{~m}$ and $2,000 \mathrm{~m}$ ), the difference in cost during operation with secondary treatment exceeds the increase in the outfall installation costs, resulting in an long-term economic advantage.
Table 8: Sewage Systems Total Cost

\begin{tabular}{cccc}
\cline { 2 - 4 } & \multicolumn{3}{c}{ Sewage Systems Cost (million US\$) } \\
\cline { 2 - 4 } & PREL+ES (1) & PREL+ES (2) & ETE-LAB \\
\hline CAPEX & 4.4 & 5.5 & 4.4 \\
OPEX & 1.7 & 1.7 & 3.1 \\
TOTAL & $\mathbf{6 . 1}$ & $\mathbf{7 . 2}$ & $\mathbf{7 . 5}$ \\
\hline
\end{tabular}

\section{Environmental Cost}

Another important factor to consideration is the environmental cost. The ETE/LAB alternative that, hypotheticaly, is proposed to be construct in the border of Guaratuba River, as shown in Figure 10, with the effluent discharge in the river, exclude, permanently, the classification of Guaratuba River, as Class 1, limiting the multiple uses of river's water, as well as, it will cause problems for bathing in Guaratuba beach. Na alternative of short marine outfall coupled to ETE-LAB, not considered in this research, will increase substantially the cost presented in Table 8. However, the marine outfall installation would enable the classification of Guaratuba River as Class 1 in its entire course, allowing the use of its waters for human consumption and ecological recreation. Also, it is important to emphasize, that the water crisis in São Paulo city has forced to get a volumetric discharge flow of $0.5 \mathrm{~m} 3 / \mathrm{s}$ river upstream (Revista Engenharia, 2015). This kind of decision during sever dry season in São Paulo metropolitan area, could affect the river dilution capacity of the effluent discharge, in this period.

When considering marine outfall alternative as a solution it is necessary an environmental analysis of the outfall discharge for the evaluation of the possible impacts of the effluent discharge in the mixing zone.

The computational simulation of the plume dispersion process of a sewage effluent in the mixing zone downstream of the effluent discharge in 


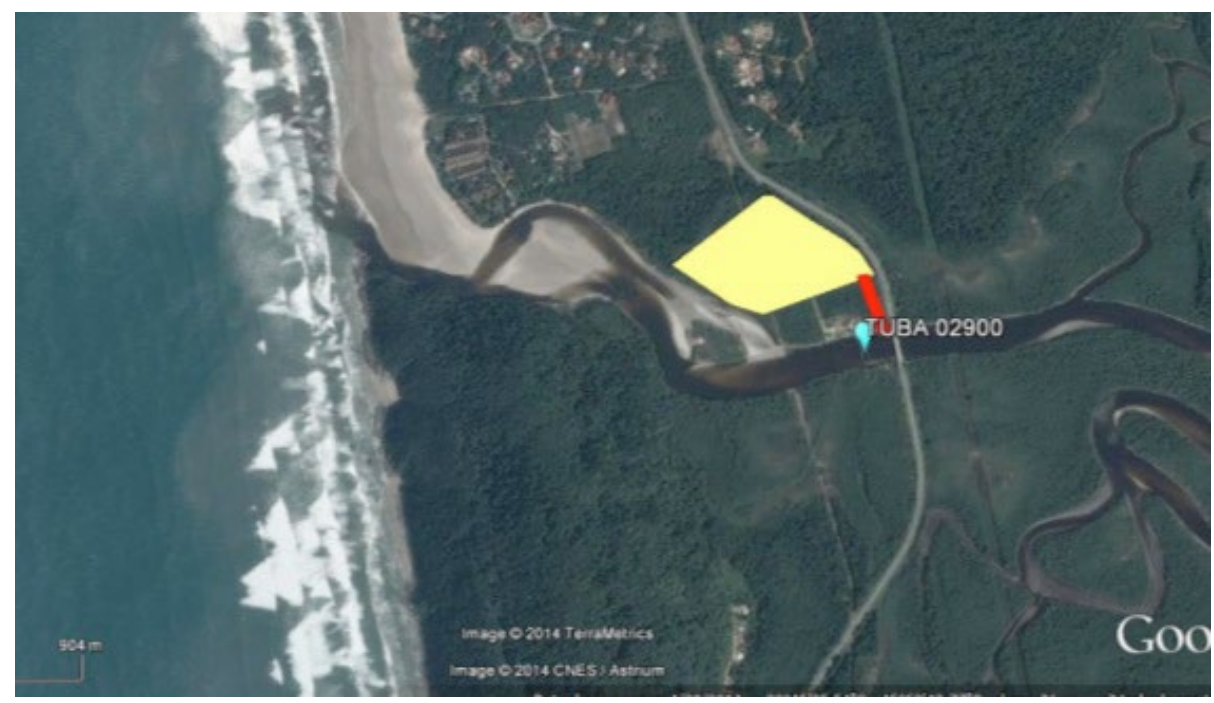

Figure 10: View of Guaratuba river in its last stretch (Ortiz et al., 2015)

the sea is nowadays an indispensable tool in the decision making process for both environmental agencies and operating companies of marine outfalls systems (Ortiz \& Bessa, 2004).

Mathematical models, which are developed to simulate the phenomena, estimate the effluent dilution as function of different parameters including, but not limited to, the discharge depth, dimension and kind of diffuser, effluent outlet velocity, density ratio between the effluent and the receiving body and the sea currents with or without stratification, allowing the simulation of different systems and the evaluation of its future performance.

In the case here presented simulations were performed using Visual Plume in order to evaluate the behavior of the initial dilution of the effluent, the concentration of fecal coliforms and phosphorus when the effluent plume reaches the surface and the distance that these occur. It was considered an effluent discharge with an initial fecal coliforms concentration of $1.7 \times 106 \mathrm{MPN} / 100 \mathrm{~mL}$ and phosphorus concentration of $8 \mathrm{mg} / \mathrm{L}$. The results of simulations can be seen in Table 9 .
The legal limits for fecal coliforms and total phosphorus, defined in the current legislation are 1000 MPN/100mL and 0,062 mg/L, respectively. As it is possible to see in Table 9 for both marine outfalls systems simulated it was reached values of initial dilution, greater to 100 .

With respect to the concentration of phosphorus it is possible to see that the legal limit is quickly reached, for both systems. In the case of fecal coliforms, although the concentration in plume, when it reaches the surface, is greater than the legal limit for the smaller outfall length, it is important to note, that this fact occurs over than $1 \mathrm{~km}$ from the protected area. Certainly, the dispersion process and bacterial decay will take care and will get pollutants values in the protected area of 300 meters much smaller than the limits.

In Figure 11 it is possible to see the evolution of the effluent plume of this system after 20 days of simulation. The phosphorus concentration was used to follow the trajectory of the plume. It is important to emphasize that limit legislation of $0.062 \mathrm{mg} / \mathrm{L}$ of phosphorus is much higher than the end of scale value represented in Figure 11. 
Table 9: Results of simulations. Initial dilution for fecal coliforms and phosphorus

\begin{tabular}{|c|c|c|c|c|c|c|c|}
\hline \multicolumn{8}{|c|}{ concentrations } \\
\hline \multirow[t]{2}{*}{ System } & \multirow{2}{*}{\multicolumn{2}{|c|}{$\begin{array}{l}\text { Nutrient parameter Initial } \\
\text { Concentration }\end{array}$}} & \multirow[t]{2}{*}{$\begin{array}{l}\text { Effluent } \\
\text { Flow } \\
(\mathrm{m} 3 / \mathrm{s})\end{array}$} & \multirow[t]{2}{*}{$\begin{array}{c}\text { Initial } \\
\text { Dilution }\end{array}$} & \multicolumn{2}{|c|}{$\begin{array}{l}\text { Distance from outlet to } \\
\text { place plume reaches } \\
\text { the surface }\end{array}$} & \multirow{2}{*}{$\begin{array}{c}\text { Nutrient } \\
\text { Surface } \\
\text { Concentration }\end{array}$} \\
\hline & & & & & $\mathbf{x}(\mathbf{m})$ & $\mathbf{y}(\mathbf{m})$ & \\
\hline \multirow{6}{*}{$\begin{array}{l}\text { PREL+ES(1) } \\
1,500 \mathrm{~m}\end{array}$} & Fecal & $1,700,000$ & & & & & $10,523.4$ \\
\hline & Coliform & $\mathrm{MPN} / 100 \mathrm{~mL}$ & 0.047 & 157.4 & -0.628 & 0.807 & $\mathrm{MPN} / 100 \mathrm{~mL}$ \\
\hline & Phophorus & $8 \mathrm{mg} / \mathrm{L}$ & & & & & $0.031 \mathrm{mg} / \mathrm{L}$ \\
\hline & Fecal & $1,700,000$ & & & & & $14,145.9$ \\
\hline & Coliform & MPN/100mL & 0.064 & 117.1 & 0.666 & 1.033 & MPN/100mL \\
\hline & Phophorus & $8 \mathrm{mg} / \mathrm{L}$ & & & & & $0.0416 \mathrm{mg} / \mathrm{L}$ \\
\hline \multirow{6}{*}{$\begin{array}{l}\text { PREL+ES(2) } \\
2,200 \mathrm{~m}\end{array}$} & Fecal & $1,700,000$ & & & & & $3,420.9$ \\
\hline & Coliform & $\mathrm{MPN} / 100 \mathrm{~mL}$ & 0.047 & 484.6 & -2.062 & 0.807 & MPN/100mL \\
\hline & Phophorus & $8 \mathrm{mg} / \mathrm{L}$ & & & & & $0.0101 \mathrm{mg} / \mathrm{L}$ \\
\hline & Fecal & $1,700,000$ & & & & & $4,968.1$ \\
\hline & Coliform & MPN/100mL & 0.064 & 333.3 & -5.204 & 1.033 & MPN/100mL \\
\hline & Phophorus & $8 \mathrm{mg} / \mathrm{L}$ & & & & & $0.0146 \mathrm{mg} / \mathrm{L}$ \\
\hline
\end{tabular}

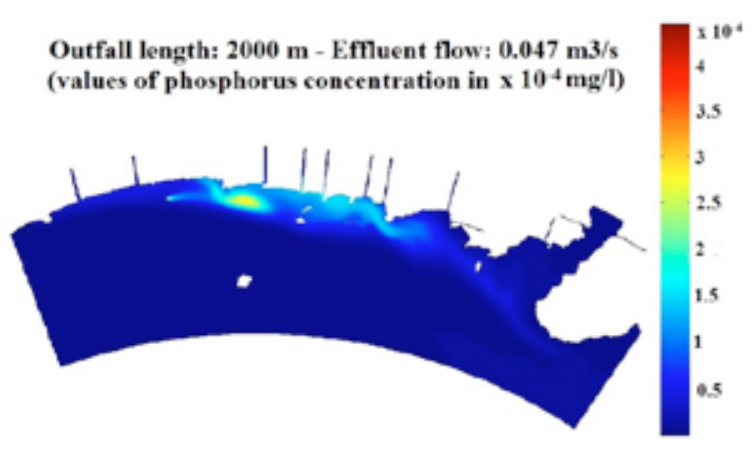

(A)

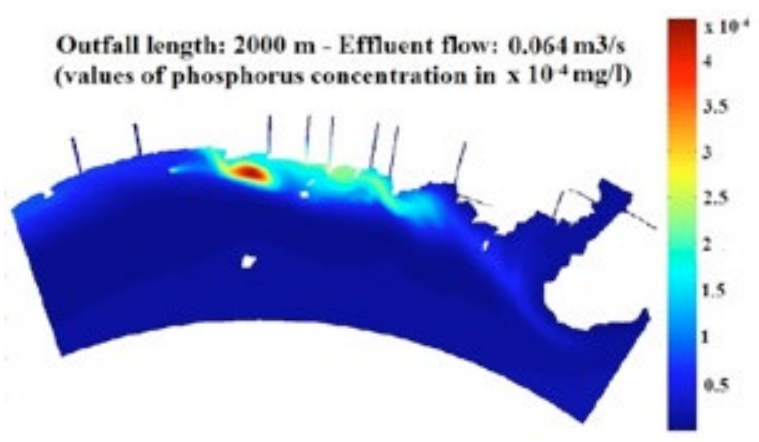

(B)

Figure 11 (A-B): Phosphorus concentration distribution after 21 days of simulation.

As a result of the study conducted here the alternative of inland preliminary treatment coupled with a 2,000 meters marine outfall is more competitive and cheaper solution when compared to the alternative of conventional treatment ETE$L A B$, particularly if a short submarine outfall is considered coupled to ETE-LAB.

From the environmental point of view, the stronger point of the marine outfall alternative would be the possibility of recovery and preserved Guaratuba water quality river, preserving its classification as a river of Class 01 according to CONAMA resolution. Figure 12 and Figure 13 showed the natural beauty of Guaratuba River.

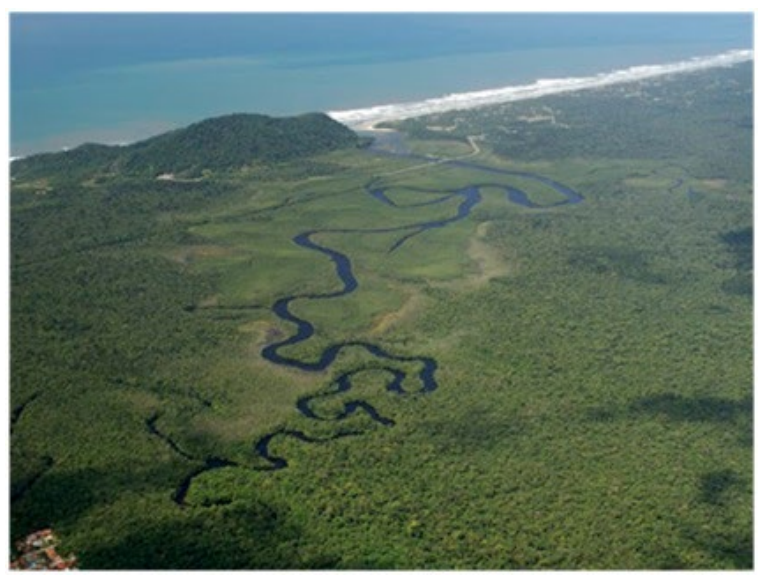

Figure 12: View of the river discharging in Guaratuba beach (Pereira et al., 2014) 


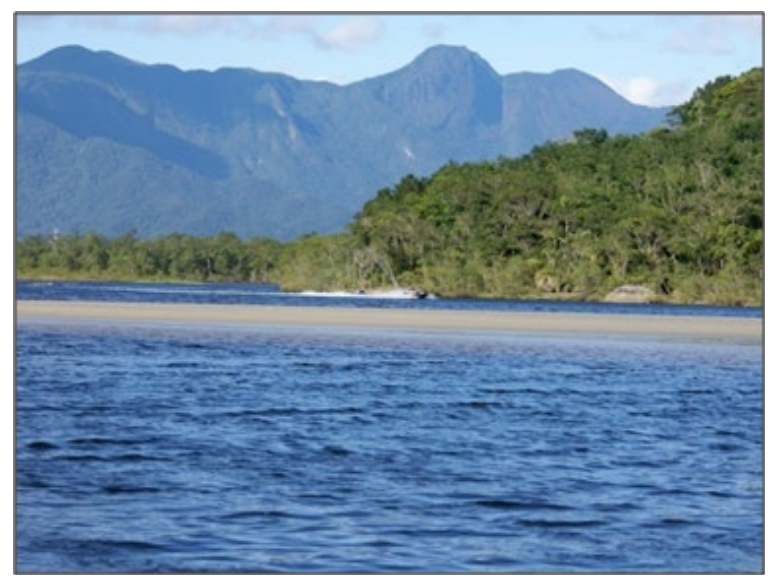

Figure 13: View of Guaratuba river in its last stretch (Pereira et al., 2014)

\section{PUBLIC CONCERN, LAWS, REGULATIONS}

The discussion presented here shows that the occupation of coastal area of São Paulo state is stressing the environment thereby implying the urgent need for applying coastal zoning legislation, planning coastal communities and improving the CONAMA (Environmental National Council) resolution for achieving sustainable development in this area. Sanitary wastewater marine outfalls must be regarded as a solution, not as a problem, although it is recognized that the planning, design, construction and operation of these systems need to be improved.

New projects must follow the best relationship for the level of treatment - outfall length/ diffusers.

A marine disposal system must consider three main actions: an executive project that adopts exhaustingly studied criteria and minimizes negative action in the aquatic environment; emergencies' actions (a contingency plan) for chemical products, solid residues and pipeline disruption; a permanent program for sea and treatment plants, as well as submarine monitoring and equipment.

In Brazil, the quality of water and the effluent discharge patterns is regulated by environmental resolutions established by the National Environment Council: CONAMA 274/2000,
$357 / 2005$ and $430 / 2011$. The $274 / 2000$ defines the proper bathing criteria of the beaches, the $357 / 2005$ introduce new parameters limits to be considered together with four classes of water for the water resources management and the 430/2011 incorporates the concept of mixing zone for marine disposal defined as "the region of the water body where the effluent initial dilution occurs", and provides the regulation of the wastewater disposal defining the conditions and standards of parameters concentrations in the point of effluent discharge. CONAMA $430 / 2011$ resolution improves the previous resolutions and incorporates the concept of ocean disposal through marine outfalls.

In São Paulo state there is also the Decreto Estadual No. 84468/76 which establishes in the Art. 18 the standard parameters for effluent discharge in interior and coastal waters.

Some coastal cities in Brazil have been approved a more restrictive municipal environmental resolution compared with CONAMA 430, concerning the use of marine outfall.

There is no room in this paper to discuss the Brazilian Environmental Legislation presented above, but one of the main conflict related with wastewater marine disposal is the type of inland treatment system do be adopted (preliminary, primary or secondary), before effluent launched in the marine outfall. Although, with the increase of the inland treatment (primary or secondary) it is possible to increase SST and DOB removal, before river or marine effluent discharge, this is not a guarantee of best effluent dilution. Primary or secondary treatment will also increase the sludge generation that must be treated and disposed properly, causing a cost increment, with an additional economic and environmental impact (Ortiz \& Sobrinho, 2013).

Although it is recognizes the evolution and the importance of the existing Brazilian environmental legislation presented above, its simple applica- 
tion does not necessarily guarantee the best solution for environmental preservation of the coastal water. It is necessary to improve this discussion so that decision makers could take in consideration technical solutions, cost benefit analysis and environmental impact, looking maximizing sustainable development in the region.

\section{CONCLUSIONS}

The main conclusions of this overview are summarized below:

- In Santos city, SABESP must continue systematic monitoring campaign of the marine outfall in the mixing zone. These monitoring data together with the channels operation data (rainwater contribution, gates operation, volumetric discharges, and channel water quality) could be the foundation for a real time database to be included in the CETESB data base water's fitness for bathing/swimming. Other cities of São Paulo coast like Guarujá and Praia Grande could adopt the same ideas.

- The option for marine outfalls in smaller communities in São Paulo coast must be considered compared with others solutions in terms of capital expenditure, operation cost and environmental impact.

- Environmental legislation could be improved through development of database like mentioned above and generating technology information possible to be applied in the coastal zone management.

- Finally, according with table 1, Clean Wave Program investments are improving a lot the standard wastewater collection and treatment, but it is necessary that these investment must be followed by coastal cities struggle to improve solutions for urban planning and irregular occupation of these regions, so that the data presented in table 1 could reflected the reality in the next years.

\section{ACKNOWLEDGEMENTS}

It is acknowledge the Coordenação de Aperfeiçoamento de Pessoal do Nível Superior (CAPES) and University of São Paulo for the scholarship support for Jacqueline Pedrera Yanes and Antonio Braulio Neto.

It is acknowledge SABESP which make available part of the data base used in this research.

\section{REFERENCES}

ABES (2005): Informe SP. Associação Brasileira de Engenharia Sanitária - ABES. Ano IX - No 5. - Jan/Fev 2005.

Arasaki, E.; Ortiz, J.P. (2006): Critérios de Decisão Aplicados aos Emissários Submarinos no Litoral Paulista. Emissários Submarinos: Projeto, Avaliação de Impacto Ambiental e Monitoramento in CETESB (2006).

CETESB (2006): Submarine outfalls: Design, Compliance and Environmental Monitoring, Book Editors: Claudia Lamparelli (CETESB) and Jayme Ortiz (EPUSP), 240 pages.

CONAMA No. 274 (2000): Resolução Conselho Nacional de Meio Ambiente - Ministério de Desenvolvimento Urbano e Meio Ambiente, Brasil.

CONAMA No. 357 (2005): Resolução Conselho Nacional do Meio Ambiente- Ministério de Desenvolvimento Urbano e Meio Ambiente, Brasil.

CONAMA No. 430 (2011): Resolução Conselho Nacional do Meio Ambiente- Ministério de Desenvolvimento Urbano e Meio Ambiente, Brasil.

Doneker, R.L.; Jirka, G.H. (2000): Expert systems for design and mixing zone analysis of aqueous pollutant discharges. Journal of Water Resources Planning and Management, ASCE, 117(6): 679-697.

ENCIBRA S.A. (2002): Elaboração dos projetos executivos das unidades de transporte, tratamento e disposição final de esgotos sanitários do sistema 3 de Praia Grande. Relatório Final. Volume III Emissários Submarinos.

FCTH (2005): Análise do sistema de disposição oceânica do litoral - Praia Grande. Relatório Preliminar - Revisão 00. Setembro/2005.

FEHIDRO (2008): Aplicação de técnicas para avaliação de impactos regionais oriundos de emissários submarinos da Baixada Santista com suporte de modelação física e numérica. Relatório FCTH.

FLUENT INC. Version 6.1 Tutorial (2003).

Garcia, R.S. (2013): Disposição Oceânica através de emissários submarinos para comunidades de menos de 50 mil habitantes. Relatório Final do Programa de Bolsa de Iniciação Científica da Pró-Reitoria de Pesquisa-PIC- Departamento de Engenharia Mecânica - USP, $16 \mathrm{p}$. 
Freitas, S; Barbosa F.O; Giordano, G. (2011): Diretrizes para projeto de sistema de disposição oceânica de esgotos para comunidade de pequeno porte. I Coletânea em Saneamento Ambiental. II. Universidade do Estado do Rio de Janeiro. Faculdade de Engenharia.

Gonçalves, F.B.; Souza, A.P. (1997): Disposição Oceânica de Esgotos Sanitários. História, Teoria e Prática. 1 ed. Rio de Janeiro, ABES, 348 p.

Gouveia, C.C; Souza, A.P; Pereira, L.P. (2002): Dimensionamento Preliminar dos Sistemas de Coleta, Transporte e Disposição Oceânica de Esgotos Sanitários: Estudo de Caso: Condomínio Morada da Praia. São Caetano do Sul: Centro Universitário Mauá de Tecnologia, $124 \mathrm{p}$.

Jirka, G.H.; Akar, P.J. (1991): Hydrodynamic classification of submerged multiport-diffuser discharges. Journal of Hydraulic Engineering, 117 (9).

Marcellino, E.B.; Macedo, L.S. (2006): Submarine outfalls: location criteria and impact minimization in the marine environment in CETESB (2006).

Ortiz, J.P.; Bessa, K.L. (2004): Modelagem computacional de descarga de efluentes em canal com análise dos campos próximo e distante. IAHR-Congresso Latinoamericano de Hidráulica. São Pedro. São Paulo.

Ortiz, J.P. (2006): CFD finite volume method technique applied to submarine and subaquatic outfalls diffusers systems. In: MWWD 2006, Antalya. MWWD \& IEMES Proccedings. Antalya : Copyright MWWD Organization.

Ortiz, J.P.; Arasaki, E.; Marcellino E.B. (2006):Visão Geral dos Emissários Submarinos no Litoral Paulista. Emissários Submarinos: Projeto, Avaliação de Impacto Ambiental e Monitoramento in CETESB (2006). p241.

Ortiz, J.P.; Alfredini, P.; Arasaki. E. (2007): Santos submarine outfall wastewater dispersion process: physical and computer modeling evaluation. FLUCOME. Tallahassee, Florida/USA.

Ortiz, J.P., Bessa, K.L., Arasaki, E., Alfredini, P. (2008) Santos, Guarujá and Praia Grande submarine outfalls: Computational evaluation of the effluent dispersion process in the Santos Bay using CFD. Proceedings of MWWD-International Conference on Marine Waste Water Discharge and Coastal Environmental.

Ortiz, J.P.; Garcia, R.S.; Subtil, E.L. (2011) New design of Santos submarine outfall: hydrodynamic modeling simulation at the Santos
Nay. Proceedings of International Symposium on Outfall Systems, Mar del Plata, Argentina.

Ortiz, J.P.; Sobrinho, P.A. (2013) Ponto de vista: O tratamento mínimo definido na legislação federal (CONAMA 430/2011) para o lançamento de efluentes sanitários em emissários submarinos é suficiente para garantir a preservação ambiental dos corpos da água?. DAE Magazine, 193, 40-43.

Ortiz, J.P.; Pereira, L.S.; Papareli, L.M., Oliveira, P.S., Pedrera Yanes, J. (2015) A comparative solution of wastewater ocean disposal through submarine outfall with a classical sequencing batching reactor treatment system. Case study Boracéia Beach-São Paulo. Proceedings IAWR World Congress - The Hague, 2015.

Pereira, L.S.; Papareli, R.M.; Oliveira, P.S. (2014): Disposição oceânica de esgoto sanitário: Emissário Submarino. Dimensionamento e Comparativo do uso de emissário com a solução convencional de ETE LAB. Trabalho de Conclusão de Curso. Escola de Engenharia Mauá.

Revista de Engenharia (2015) Crise Hídrica: O Futuro do Abastecimento. Instituto de Engenharia, edição 625.

SABESP (2006). Programa de monitoramento ambiental da área sob influência dos emissários submarinos de esgotos de Santos/ São Vicente e Praia Grande Subsistemas 1, 2 e 3. Relatório Final. São Paulo, 2006.

SABESP (2013): Monitoramento Ambiental do Canal de São Sebastião no entorno do emissário de Itaquanduba. Relatório Técnico Final Referência 62.995. Grupo Falcão Bauer.

\section{SABESP (2014): Relatório Programa Onda Limpa Baixada Santista.}

SNIS (2007): Diagnóstico dos Serviços de Água e Esgoto - 2007. Sistema Nacional de Informações sobre Saneamento. http://www. snis.gov.br/diagnostico-agua-e-esgotos/diagnostico-ae-2007

Souza, J.F., Azebedo, J.L., Oliveira, L.R., Soares, I.D. (2007): Emissários submarinos, uma alternativa para a disposição final de efluentes em cidades costeiras. Departamento de Física Universidade Federal do Rio Grande.

Subtil, E.L.; Mierzwa, J.C.; Ortiz, J.P.; Robinson, R.S.; García, A.; Alba, J.G. (2011): Study of the influence of chemically enhanced primary treatment (CEPT) in the water quality of Santos submarine outfall using an eutrophication numerical model. Proceedings of the International Symposium on Outfall Systems. Mar del Plata, Argentina. 